\title{
DETERMINATION FOREST ROAD ROUTES VIA GIS-BASED SPATIAL MULTI-CRITERION DECISION METHODS
}

\author{
ÇALIŞKAN, E. $.^{*}-$ BEDIROGLU, Ş. $^{2}-$ YILDIRIM, . ${ }^{2}$ \\ ${ }^{1}$ Department of Forest Engineering, Faculty of Forestry, Karadeniz Technical University \\ 61080 Trabzon, Turkey \\ ${ }^{2}$ Faculty of Engineering, Karadeniz Technical University, 61080 Trabzon, Turkey \\ ${ }^{*}$ Corresponding author \\ e-mail: caliskan@ktu.edu.tr
}

(Received 20 $0^{\text {th }}$ Sep 2018; accepted $28^{\text {th }}$ Nov 2018)

\begin{abstract}
Forest road route determination is a complex process in which a number of variables should be analyzed simultaneously and it is one of the most important process steps for forest road projects. For this purpose, the factors that are effective on forest road routes should be primarily determined. The effects of each factor should be determined as a weighting coefficient and they should be evaluated and analyzed as a whole. Since the factors with impact on forest road routes are considered a necessity, the management of intense spatial data sets emerges. The analysis of such intense data sets and obtaining quick and accurate results are possible by way of decision support systems known as Geographic Information Systems (GIS). In this study, forest road route determination was carried out using a decision-support system called FOROR (Forest Road Route) developed by us which is a raster-based system, based on GIS technologies. FOROR software is an application that combines GIS and MCDM principles. Manuel provides long-term analysis and benchmarking. Visual Studio and Devoloper for ArcGIS had been used for creating FOROR. ArcPy, Python programming language had been used at FOROR. In this context, the factors that are effective on forest road routes were determined after which the necessary geographic data layers were identified based on these factors which were then classified according to the standards. For this application, Analytical Hierarchy Process (AHP), Simple Additive Weighting (SAW), Fuzzy Overlay, Promethee and TOPSIS methods of Multi-Criteria Decision Methods (MCDM) were used. Study area is located at Black Sea region of Turkey. Analyses were performed using five different methods for the determination of forest routes; five different routes were found accordingly and these routes were compared to each other as well as to the existing road. The advantages provided by MCDM with support of Geographic Information System for forest road route determination were put forth as a result of the study.
\end{abstract}

Keywords: forest road route, spatial multi-criteria decision making, AHP, SAW, TOPSIS, Promethee, Fuzzy Overlay, GIS

\section{Introduction}

Forest roads are among the most important infrastructure facilities for forestry operations which are also renewable natural resources. Forestry operations include forest road design and slope stability, analysis of harvesting systems for economic efficiency and site protection, planning and scheduling of harvests in addition to transportation systems. It is necessary to establish a road route which will enable the achieving of targets in order to plan forestry operations within the frame of sustainability concept. There are numerous studies in which GIS has been used for route determination. GIS is essential in trail route planning with an objective of applying and evaluating a GIS-based methodology for determining optimal recreational trail routes using key information items (Chiou et al., 2010). There is a need for development of spatial data infrastructure that improves the access to reliable information for sustainable management of the forest 
and its wildlife resources (Nino et al., 2017; Arpacik et al., 2017). A significant issue in the field of object modeling is proper representation of objects in the real world within a geographical information system (GIS) environment (Sadeghi-Niaraki et al., 2011). However, the number of criteria and approaches that have been adopted in these studies vary significantly. While only a single criterion, such as landslide, is taken into consideration in some studies, others evaluate several criteria simultaneously. Selection was made in some studies among the alternatives created by evaluating the effects of the proposed road, whereas in others the area where the road will be built was evaluated in terms of several criteria after which the best alternatives were attempted to be designed.

Spatial planning of urban forest development can be carried out more easily and quickly within GIS (Narulita et al., 2016). Conventional road planning methods based on topographic maps do not allow forest engineers to create a sufficient number of road alternatives (Chung and Sessions, 2001). If the alternatives are not evaluated in the process of choosing the optimum route, the engineers cannot guarantee that the selected route is the best which minimizes the environmental effects around the route. Chen and Koprwoski (2016) have made a good study for saving the habitat and ecosystem. Environmental factors must be taken into consideration as a geodatabase for saving the ecosystem. The terms that environmental factors correspond to are; rivers, lakes, protected areas, soil quality and natural resources. Rapaport and Snickars (1998) carried out a study in which they determined a road route that minimizes the environmental effects with a low-cost while enabling enables transportation in the shortest period of time by way of GIS techniques. Lee and Stucky (1998) developed an algorithm for finding the lowest-cost road route depending on the topography factor and tested it via field work. Sadek et al. (1999) carried out a study in which a GIS platform was developed that brings together the content necessary for the multi-criteria evaluation of route alternatives.

A number of computer-assisted and GIS-based models have been developed in recent years for determining the forest road routes automatically. TRACER (Akay and Sessions, 2005) and PEGGER, ROUTES (Rogers, 2005; Reutebuch, 1988) can be mentioned. Several scientific studies were carried out in Turkey in which computer software (Demir, 2007; Demir and Öztürk, 2004) and GIS methods (Altunel, 2000; Gümüş and Erdaş, 2000; Gümüş, 2008; Akay et al., 2008) were utilized. Yu et al. (2003) developed an algorithm to determine road routes by using raster-based GIS abilities. This algorithm provides solutions which can be used for determining the locations of art structures such as bridges and tunnels along the route.

Forest road location knowledge is coupled with planning models and decision-making tools implemented in geographic information systems (Sačkov et al., 2014). Saha et al. (2005) determined the optimum road route in areas under landslide danger in Himalayas using a GIS-based method. In this study, landslide danger zones, land use, drainage conditions (drainage intensity, creek frequency etc.) and lithological structure were taken into consideration in determination of the road route. Sadeghi-Niaraki et al. (2011) aimed to create a model for determining the best possible road route in a road network by using GIS technologies. They formed a model using Analytical Hierarchy Process (AHP) method and adding variables such as velocity, time weather, address information and road type to the road network model. The defined variables were combined by using the resistance model method in AHP. The variables were subject to sensitivity analysis in the final stage and the developed model was tested using a raster-based GIS model with Multi-Criteria Decision Making (MCDM) methods for determining the optimum 
transportation route with the minimum cost for heavy vehicles (Choi et al., 2014). He created the model with a fuzzy logic which was formed by using multiple criteria (velocity, water mass, material size, curve, visibility, distance, road, maintenance etc.) simultaneously so that it can evaluate the total weight of the movements of heavy vehicles.

MCDM methods are interactive and flexible tools for the analysis of complexity among the alternatives which contain different environmental and socio-economic factors. Combining GIS and MCDM techniques provides convenience to the users in determining the various alternatives of criteria and objects with multiple and complex structures. Some researchers have been performing road network analyses using GISbased road structure and MCDM by considering factors such as wood volume, slope, soil condition as well as the distance between existing forest roads, soil type, geology, hydrography, elevation and tree type in addition to environmental factors (Sadek et al., 1999; Hosseini and Solaymani, 2006; Jusoff, 2008; Mohammadi Samani et al., 2010; Hayati et al., 2012; Çalışkan, 2013; Stergios et al., 2015).

There has been a rapid increase in the interest towards and research on GIS based MCDM methods in recent years. MCDM is a routine activity that is common to individuals and organizations. Selection of the suitable route in planning of forest roads is a complex engineering problem depending on various factors. In this respect, utilization of GIS technologies and spatial multi-criteria decision making methods (MCDM) are required.

It was observed as a result of examining the existing forest road projects that the building cost is higher than the budget of the project due to incorrect route determination, the that environmental effects exceed acceptable limits and that geologically unfavorable areas are being used. As far as GIS is concerned, it significantly simplifies the vehicle routing optimization process, representing, visualizing efficiently and conveniently the obtained results and reducing costs (Zsigraiova et al., 2013). Therefore, in terms of optimum management of resources, forming a GIS-based, and effective route determination model for the forest roads in Turkey is of significant importance. No study has been carried out in Turkey for determining the forest routes which considers the whole major factors (slope, geological structure, rivers, lakes, protected areas, soil quality and natural resources) using raster-based advanced GIS as well as MCDM techniques with special extensions for.

Forest road route determination in this study was carried out dynamically using a raster-based decision-support system. An ArcGIS extension called FOROR (Forest Road Route) was developed for this purpose based on GIS technologies. In this respect, the primary factors with impacts on the forest road route along with the necessary geographic data layers were determined and classified according to the standards. For this application, Analytical Hierarchy Process (AHP), Simple Additive Weighting (SAW), Fuzzy Overlay, Promethee and TOPSIS methods of MCDM were used. Lack of these works is this, we could not see any model considering 5 different MCDM techniques at same extension. Analyses were carried out using five different methods for determining the the forest route as a result of which five different routes were found which were then compared among each other as well as with the existing road.

The purpose of this study is to test multi-criteria decision-making methods in determining forest roads. Five different MCDM methods have been automatically tested by means of special GIS software. Thus, new road routes that are economically feasible and sensitive to the environment have been determined. 


\section{Material and Methods}

\section{Study Area}

Trabzon Province is situated between longitude $39^{\circ} 7^{\prime} 30^{\prime \prime}$ and $40^{\circ} 30^{\prime} \mathrm{E}$ and latitude $40^{\circ} 30^{\prime}$ to $41^{\circ} 7^{\prime} \mathrm{N}$ in central Eastern Black Sea region of Turkey (Figure 1). Eastern Black Sea region and also the city of Trabzon is green-field and has a great tree diversity due to rainy climate. There are many different stands at Trabzon and in case study area chosen. Determining an optimum route for a road in this area is a challenge. The location of the study area has been shown in Fig. 1 .

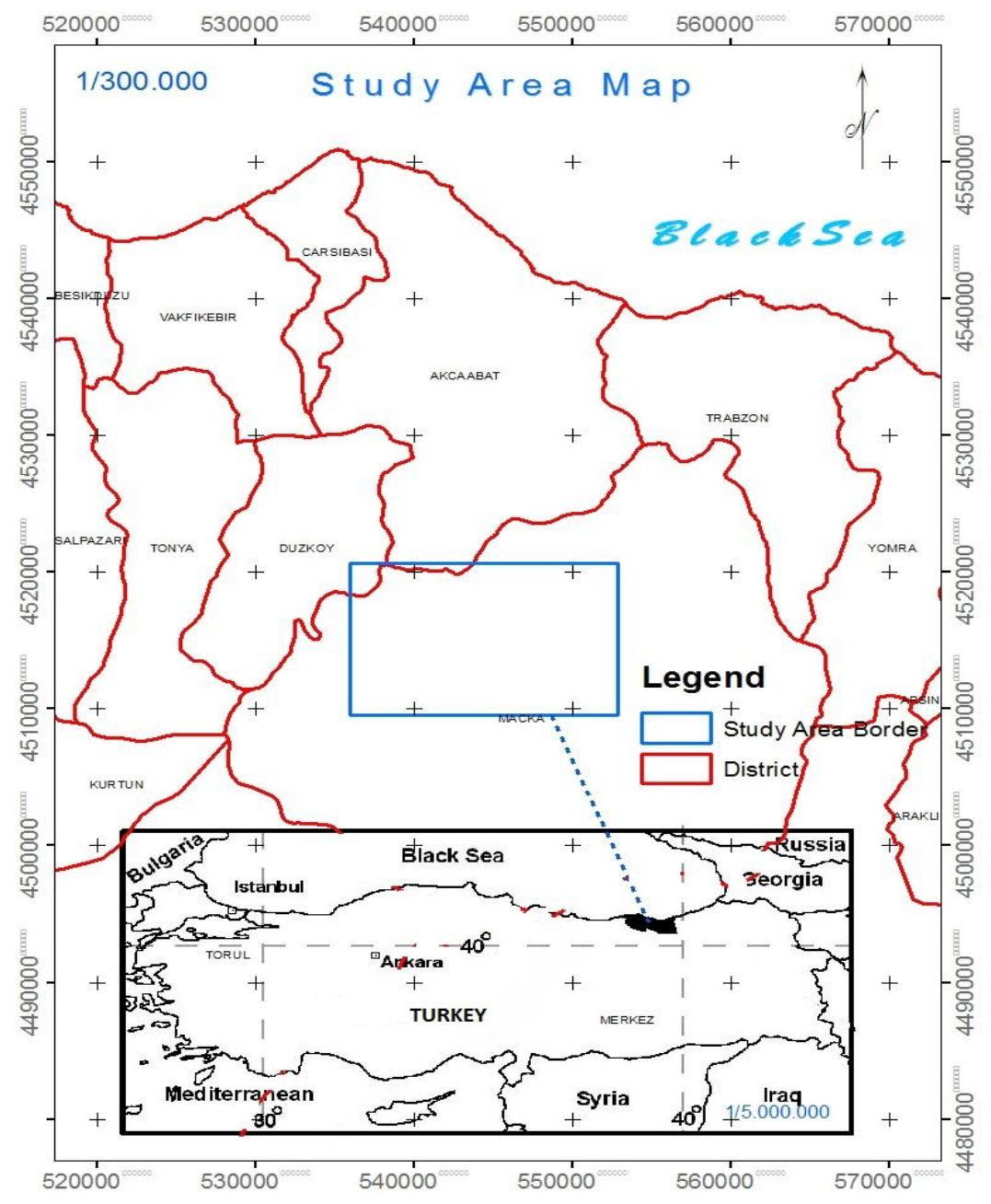

Figure 1. Location of the study area

The process steps for the application in this study has been shown and explained briefly in Fig. 2. The first step was determining factors and sub-factors and determining the weights of factors as analysis criteria. These factors were assigned from academic studies, context sensitive application projects and interviews with experts on this area. These factors and sub-factors and their weights shall be explained briefly in the next section of this paper. The next step was generating a spatial database coherent with factor and sub-factors. The spatial datasets were then analyzed using our special Forest 
Road Route (FOROR) extension running at ArcGIS/ArcMap software. Finally, the acquired results were compared and relevant information was provided in the form of tables and verbal discussions.

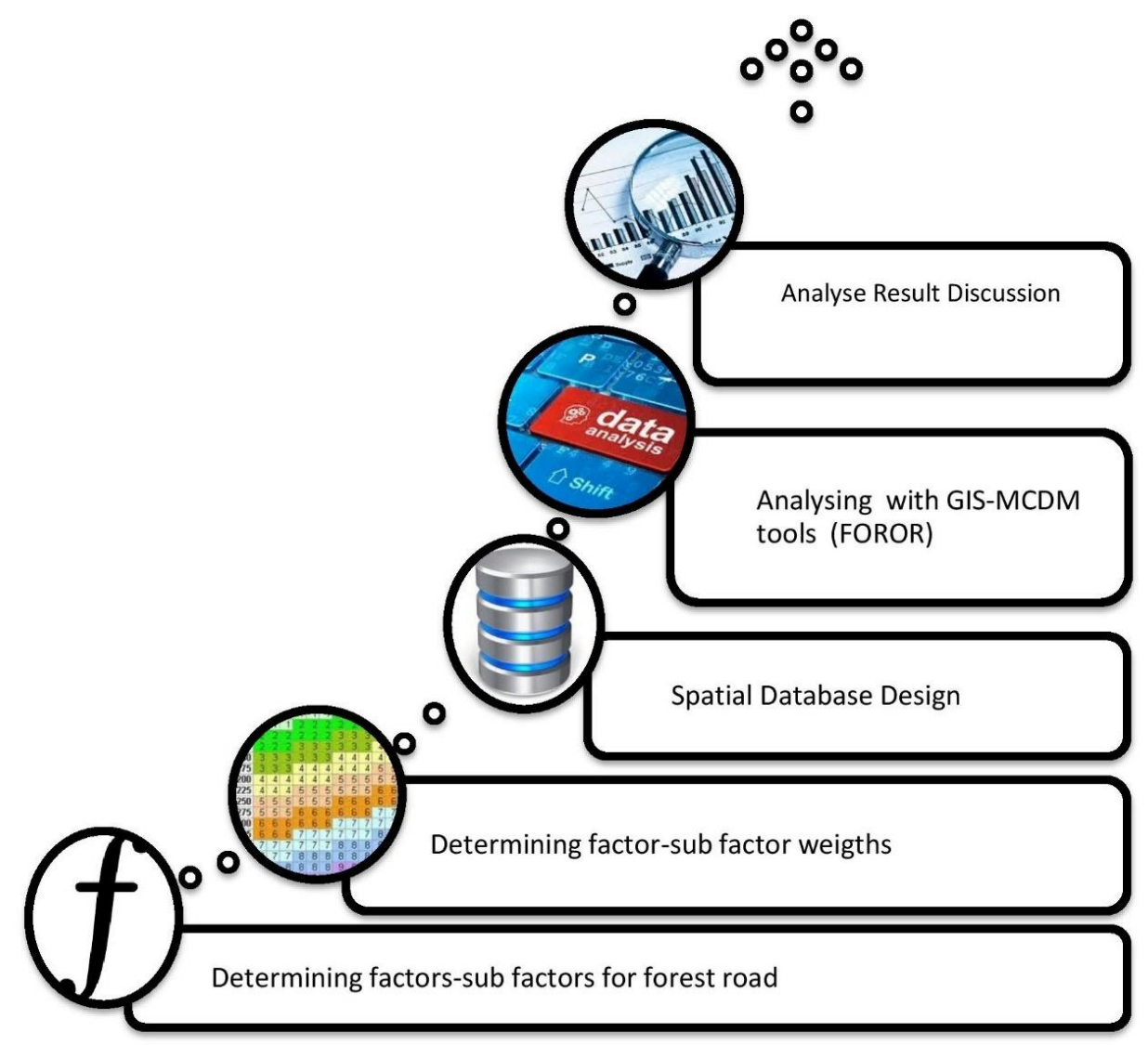

Figure 2. Graphical representation of the workflow

\section{Factors, sub factor and their weights}

MCDM is a comprehensive technique and the determination of factor, sub-factor weights was a challenging problem. There are many various approaches in literature for determining weights. The weights were determined in this study by way of interviews with academicians, private sector and forest engineering staff working at similar route determination areas. The objective of the interviews carried out was to get a personal idea of professionals working at route determination studies. Interviews were carried out with 15 academicians working on similar areas such as, geomatics, forestry, civil engineering etc. There was a total of 8 private sector employees to whom we applied for interviews. In addition, 11 forest engineers working at government organizations participated in our interview. Finally, the weights were compared with the relevant studies in literature as a result of which it was put forth that there are no statistically significant differences between our weights and the weights used in various previous studies. Some of these comparison studies are: Bagli, 2011; Kiker et al., 2009; Malczewski, 2007; Malczewski, 1999; Joerin et al., 2001. The weights of factors and sub-factors are given in Table 1. Sub-factor weights were indicated directly and factor 
weight at SAW order for generating relative rank idea in researcher's mind between factors. Detailed weights of each factors in AHP, TOPSIS, Promethee or Fuzzy Overlay can be seen in Table 2 .

Table 1. Factors, sub factor weights

\begin{tabular}{|c|c|c|c|}
\hline CRITERIA & (Factor) PASS & (Sub Factor) Weight & SAW Order (Rank) \\
\hline Avalanche & Pass & 9 & 6 \\
\hline Erosion & $0-250$ meters & - & 5 \\
\hline \multirow{5}{*}{ Rivers } & 100 meters & 9 & 2 \\
\hline & 200 meters & 7 & \\
\hline & 300 meters & 5 & \\
\hline & 400 meters & 3 & \\
\hline & 500 meters & 1 & \\
\hline Protected areas & Pass & Restricted & 8 \\
\hline Natural resources & 250 meters & 9 & 9 \\
\hline \multirow{3}{*}{ "Soil } & 4. degree & 5 & 3 \\
\hline & 6. degree & 3 & \\
\hline & 7. degree & 2 & \\
\hline \multirow{4}{*}{ Geology } & Kru 1-2-3 & 1 & 4 \\
\hline & Gama 2-3 & 7 & \\
\hline & Jlh-Jkr & 5 & \\
\hline & Alv & 4 & \\
\hline \multirow{5}{*}{ Land cover } & Meadow & 1 & 7 \\
\hline & Nut & 7 & \\
\hline & Dry-agric. & 5 & \\
\hline & Forest & 3 & \\
\hline & Settlement & Restricted & Restricted \\
\hline \multirow{6}{*}{ Slope } & $0-5$ & 1 & 1 \\
\hline & $5,01-10$ & 3 & \\
\hline & $10,01-20$ & 5 & \\
\hline & $20,01-30$ & 7 & \\
\hline & $30,01-40$ & 9 & \\
\hline & $40,01-90$ & 9 & \\
\hline
\end{tabular}

*Soil type is shown with numbers from 1 to 9.1 is the best quality soil for agriculture or other usages, other side 9 is poor quality soil. All the geographic dataset was taken from related governmental resources and then reorganized. "SAW" order is rank of each factor in SAW MCDM technique. Pass means definition of intersection between each route and related factor's geographic dataset

A comparison difference index (CDI) formula applicable for all MCDM methods as a self-technique for comparing evaluations was generated. First of all, it can be be seen as a complicated formula but it is too easy to use and calculate. Calculation formula for comparing final routes is given below;

$$
C D I=\sum\{[1-(y / 2 z)] * x * t\}
$$

where, $x$ : Pass Value due to related factor in meters (line polygon intersection value), $y$ : SAW rank in number, $z$ : Total factor count, $t$ : Sub factor point (determined with interview). 


\section{Designing Geodatabase}

A geographic database was created in ESRI ArcGIS 10.3 software and projected to Universal Transverse Marketer (UTM) projection, zone 36N. Maps were rectified, digitized, projected and imported to the geographic database.

An accurate and updated geodatabase was created consisting of geographic layers within factors. Geographic layers were redesigned flowingly due to sub-factors included in the factors. These geodatabase layers were; rivers, ways, slope, soil type, geology, erosion, avalanche, natural resource, protected areas and land cover map of area. Some of these geographic layers have been shown in Fig. 3.

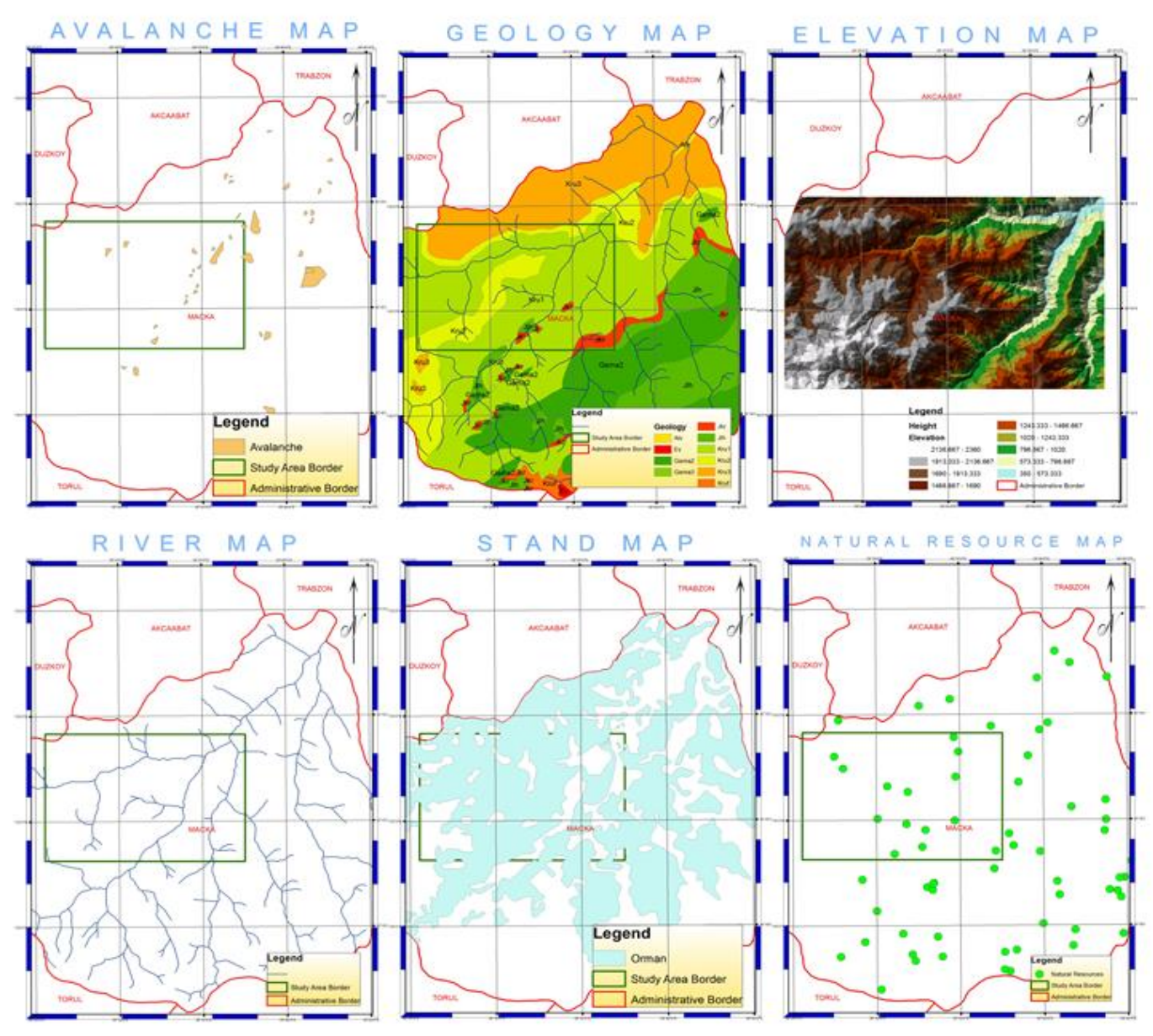

Figure 3. Maps of some geographic layers in Geodatabase

\section{Methodology}

The methodology of this paper was based on the principles GIS and MCDM. Common MCDM rules and formulae have been used for calculating factor and subfactor weights with our special GIS extension (FOROR) (Çalışkan et al., 2016). The calculated factor and sub-factors were then included as part of the GIS analysis processes. GIS analysis processes were interpolating heights and building TIN, ringbuffer for river, way etc. point or polyline data and then merging them with the study area border, interpolating some sample data (like population) with Kriging or Invert 
Distance Weighting (IDW) as geostatistical coherent interpolation techniques and reorganizing polygon data before applying raster to vector conversation. Kriging interpolation is generally used for population interpolations, estimations. On the other hand, IDW is used for analysis such as pollution or density clustering analysis. Finally, all the geospatial dataset prepared in vector format was clipped to the study area border which was then converted to raster format in equivalent pixel values for calculating the accumulated cost surface. A conversion to raster format was performed using a cell size of 30x30 m. Cost distance-cost path algorithms were applied to accumulated surfaces and optimum routes were found. There are various algorithms such as Berry, Dijkstra etc. The Cost Distance function creates an output raster in which each cell is assigned the accumulative cost to the closest source cell. The algorithm utilizes the node/link cell representation. Summary explanations and mathematical formulae have been given below this section as well as results of some GIS analyses shown with figures. Our extension includes 5 MCDM same methods. We can apply 5 different calculations for the same geodatabase. Five different methods have been given below.

\section{Multicriteria Techniques}

There are 5 well known MCDM techniques used in this study; which are TOPSIS, SAW, Fuzzy Overlay, AHP and Promethee. These techniques have different mathematical formulae and verbal definitions. In this section, their formulae have been acquired from academic studies with less verbal definitions because they have long process steps.

\section{TOPSIS Method}

TOPSIS is generated by Yoon and Hwang in 1980 and uses common approaches of ELECTRE method. TOPSIS includes six step processes.

- Step 1: Creating performance decision matrix.

$$
A_{i j}=\left[\begin{array}{cccc}
a_{11} & a_{12} & \ldots & a_{1 n} \\
a_{21} & a_{22} & \ldots & a_{2 n} \\
\cdot & & & \cdot \\
\cdot & & & \cdot \\
\cdot & & & \cdot \\
a_{m 1} & a_{m 2} & \ldots & a_{m n}
\end{array}\right]
$$

- Step 2: Calculating the normalized decision matrix $\left(\mathrm{R}_{\mathrm{ij}}\right) . \mathrm{r}_{\mathrm{ij}}$ here is normalized value.

$$
r_{i j}=\frac{a_{i j}}{\sqrt{\sum_{i=1}^{m} a_{i j}^{2}}}
$$

$i=1,2, \ldots, m ; j=1,2, \ldots, n$. 
$\mathrm{R}$ matrix is obtained as the formula below:

$$
R_{i j}=\left[\begin{array}{cccc}
r_{11} & r_{12} & \ldots & r_{1 n} \\
r_{21} & r_{22} & \ldots & r_{2 n} \\
\cdot & & & \cdot \\
\cdot & & & \cdot \\
\cdot & & & \cdot \\
r_{m 1} & r_{m 2} & \ldots & r_{m n}
\end{array}\right]
$$

- Step 3: Calculating the weighted normalized decision matrix. The weighted normalized value $V_{i j}$ is calculated as follows:

$$
V_{i j}=\left[\begin{array}{cccc}
w_{1} r_{11} & w_{2} r_{12} & \ldots & w_{n} r_{1 n} \\
w_{1} r_{21} & w_{2} r_{22} & \ldots & w_{n} r_{2 n} \\
\cdot & & & \cdot \\
\cdot & & & \cdot \\
\cdot & & & \cdot \\
w_{1} r_{m 1} & w_{2} r_{m 2} & \ldots & w_{n} r_{m n}
\end{array}\right]=\left(R_{i j} \times V_{n \times n}\right)
$$

- Step 4: Ideal $\left(A^{*}\right)$ and Negative ideal $\left(A^{-}\right)$Solutions.

$$
\begin{aligned}
A^{*} & =\left\{\left(\max _{i} v_{i j} \mid j \in J\right),\left(\min _{i} v_{i j} \mid j \in J^{\prime}\right\}\right. \\
A^{-} & =\left\{\left(\min _{i} v_{i j} \mid j \in J\right),\left(\max _{i} v_{i j} \mid j \in J^{\prime}\right\}\right.
\end{aligned}
$$

- Step 5: Calculating separation measures with Euclidian distance.

$$
\begin{aligned}
& S_{i}^{*}=\sqrt{\sum_{j=1}^{n}\left(v_{i j}-v_{j}^{+}\right)^{2}} \\
& S_{i}^{-}=\sqrt{\sum_{j=1}^{n}\left(v_{i j}-v_{j}^{-}\right)^{2}}
\end{aligned}
$$

$\mathrm{i}=1,2, \ldots, \mathrm{m}$ and $\mathrm{j}=1,2, \ldots, \mathrm{n}$.

- Step 6 (Last Step): Calculating proximity to ideal solution.

$$
C_{i}^{*}=\frac{S_{i}^{-}}{S_{i}^{-}+S_{i}^{*}}
$$


Here, $C_{i}^{*}$ is given a value between $0 \leq C_{i}^{*} \leq 1$ and $C_{i}^{*}=1$ indicating the proximity of the related decision points to the ideal solution, $C_{i}^{*}=0$ decision points' negative proximity to ideal solution (Yaralioglu, 2004). The factor and sub-factor weights were calculated using TOPSIS.

\section{SAW Method}

The mathematic formulation of the method was described by an equation and a simple formula (Kontos et al. 2005);

$$
V_{i}=\sum_{j=1}^{n} w_{j} v_{i j}
$$

where, $V_{i}$ is the suitability index for the area $i, w_{j}$ is the relative importance weight of criterion $j, v_{i j}$ is the grading value of area $i$ under criterion $j, n$ is the total number of criteria. The factor and sub-factor weights were calculated using SAW (Yildirim et al., 2017).

\section{Fuzzy Overlay Method}

The equation using fuzzy Gaussian function can be given as:

$$
\mu x=e-f 1 * x-f 2
$$

where, the inputs to the equation $f 1$ and $f 2$ are the spread and the midpoint, respectively (Baidya et al, 2014). The factor and sub-factor weights were calculated using Fuzzy overlay.

\section{AHP Method}

AHP is a multi-objective, multi-criteria decision-making approach, which enables the decision maker to arrive at a scale of preference drawn from a set of alternatives. It helps decision makers find out the best suits their goal and their understanding of a complex problem with multiple conflicting and subjective criteria (Ezzabadi et al., 2015; Saaty, 1980). The factor and sub-factor weights were calculated using AHP.

$$
\begin{gathered}
A_{i} P A_{j} \rightarrow a_{i j}>1 \\
A_{i} I A_{j} \rightarrow a_{i j}=1 \\
a_{i j}=1 / a_{i j} \\
a_{i j}=1 \\
\left(\mathrm{~A}-\lambda_{\max } \mathrm{I}\right) \times \mathrm{w}=0 \\
a_{i j}=a_{i k} \times a_{k j} \\
\mathrm{w}_{p}=\mathrm{W}_{p} \times \mathrm{W}_{p-1} \times \ldots \mathrm{W}_{3} \times \mathrm{w}_{2}
\end{gathered}
$$


AHP provides measures of inconsistency as a function of the deviation between $\lambda \max$ and $n$. Finally, global priorities at each node of the hierarchy were calculated by weighting the local priorities with the weights of the corresponding parent nodes. When $\mathrm{wk}-1$ is the vector of global priorities (weights) of the elements in the level $(\mathrm{k}-1)$, Wk is the matrix of local priorities of the level $\mathrm{k}$ with respect to elements of level $(\mathrm{k}-1)$. The global priorities at the level $\mathrm{k}$ are given by $\mathrm{wk}=\mathrm{Wk} \times \mathrm{wk}-1$. Since local and global priorities are the same at the second level $(\mathrm{w} 1=[1])$, the global priorities at level $\mathrm{p}$ can be computed using Equation (Yildirim et al., 2017). The factor and sub-factor weights were calculated using AHP.

\section{Promethee Method}

First of all, a particular preference function need to be determined $(\operatorname{Pj}(a, b))$ in order to translate deviation between the evaluations of two alternatives ( $a$ and $b$ ) on a specific criterion (gj) into a preference degree ranging from 0 to 1 . Preference scores of alternatives on a certain criteria are derived from (fj(a)-fj(b)), as shown in Equation 20 (Murat et al., 2015).

$$
\mathrm{Pj}(\mathrm{a}, \mathrm{b})=\mathrm{Gj}\{\mathrm{fj}(\mathrm{a})-\mathrm{fj}(\mathrm{b})\}
$$

Relative importance (weights) of each criterion needs to be assigned. Within this content, an overall preference index $(a, b)$ can be computed via taking all the criteria into account (see Equation 21). This preference index is based on the positive $\varphi^{+}($a) and negative $\varphi^{-}$(a) preference flows for each alternative, which measures how an alternative (a) is outranking (see Equation 22) or outranked (see Equation 23) by the other alternatives. The difference between these preference flows is represented as the net preference flow $\varphi$ (a) (see Equation 24) (Murat et al., 2015).

$$
\begin{gathered}
\pi(a, b)=\sum_{j=1}^{k} w_{j} P_{j}(a, b) \\
\varphi^{+}(a)=\frac{1}{n-1} \sum_{b} \pi(a, b) \\
\varphi^{-}(a)=\frac{1}{n-1} \sum_{b} \pi(b, a) \\
\varphi(a)=\varphi^{+}(a)-\varphi^{-}(a)
\end{gathered}
$$

The positive preference flow $\varphi^{+}\left(\mathrm{a}_{\mathrm{i}}\right)$ quantifies how a given action $\left(\mathrm{a}_{\mathrm{i}}\right)$ is globally preferred to all the other actions while the negative preference flow $\varphi^{-}\left(a_{i}\right)$ quantifies how a given action $\left(a_{i}\right)$ is globally preferred by all the other actions. An ideal action would have a positive preference flow equal to 1 and a negative preference flow equal to 0 . The two preference flows induce two generally different complete rankings on the set of actions. The first one is obtained by ranking the actions according to the decreasing values of their positive flow scores. The second one is obtained by ranking the actions according to the increasing values of their negative flow scores. The 
Promethee I partial ranking is defined as the intersection of these two rankings. As a consequence, an action $\left(a_{i}\right)$ will be as good as another action $\left(a_{j}\right)$ if;

$$
\varphi^{-}\left(\mathrm{a}_{\mathrm{i}}\right) \geq \varphi^{-}\left(\mathrm{a}_{\mathrm{j}}\right) \text { and } \varphi^{-}\left(\mathrm{a}_{\mathrm{i}}\right) \leq \varphi^{-}\left(\mathrm{a}_{\mathrm{j}}\right)
$$

The factor and sub-factor weights were calculated using Promethee (Toinard et al., 2015).

\section{Creating forest road route determination extension tool}

A new GIS and MCDM extension has been developed for ArcMap 10.3 for the purposes of accelerating the process steps, minimizing human-user mistakes and adding special custom-defined algorithms. Microsoft Visual Studio and ArcGIS SDK (Software Developer Kit) for Python were used with ArcObject libraries. This extension named FOROR is a comprehensive tool that automates all analyses and discussion steps (Çalışkan et al., 2016). After the vector based GIS files are opened in addition to giving factor and sub factor weights, it just remains to choose the analysis patterns pre-defined on the tool. The tool consists of all related GIS functions such as Vector-Raster conversion, GIS Analysis (Buffer, Intersect, Overlay etc.), Kriging-IDW Interpolations, Accumulated Cost Surface Calculation and finding optimum routes with Cost Distance Cost Path Algorithms. The extension needs a .mxd file containing related geographic dataset in vector format. You are then directed to enter quantities of your factor, subfactor weights, points and other related information. TOPSIS, SAW, PROMETHEE, AHP and FUZZY OVERLAY algorithms and mathematical formulas also included into extension.

\section{Sensitivity Analysis}

Sensitivity analysis was used to examine the sensitivity of the routes subject to changes in variable weights. This is useful in circumstances where uncertainties exist with regard to the definition of the importance of different route-related variables. In many cases, it is also important to know how the results will change if the weights are changed (Sadeghi-Niaraki et al., 2011). Sensitivity analysis allows the determination of the level of accuracy required for a parameter to make the model sufficiently useful and valid. There are many different sensitivity techniques in literature if MCDM calculations and GIS analysis are sensitive to any changes of parameters. Changing factors, sub-factors or changing order of criteria are well known and commonly used techniques.

\section{Results and Discussion}

By applying the described methodology, we obtained the relevant data for all five variants of the forest road route; analyzed, evaluated and compared them after which we selected the one that best suits the methods. GIS based MCDM analyses were applied on geodatabase using our case-sensitive extension (FOROR). Buffer analysis, interpolations, normalizations and vector-raster conversions were carried out automatically for the given factor, sub-factor points and other values. Analysis steps have been shown briefly in Figure 2 (Workflow Diagram) and the relevant steps were explained in previous sections. The result maps and related tables generated by the 
extension are shown automatically in this section. Figures 4, 5, 6, 7, 8 show the resulting forest road route generated for each MCDM technique and the current forest road used at the field. Each MCDM result route has different flows but at first sight AHP and TOPSIS have closed flows on the map since their mathematical formulas and algorithms are similar.

All factors which affect forest road routes will not, of course, have equal effects on each route. Therefore, in the factor weights and sub-criteria weights should be determined in order to take this variation into account. In the context of this study, it was considered that AHP, TOPSIS, SAW, Promethee and Fuzzy overlay methods from the Multi-Criteria Decision Making (MCDM) methods are suitable after which the weights of the factor and sub-criteria were determined.

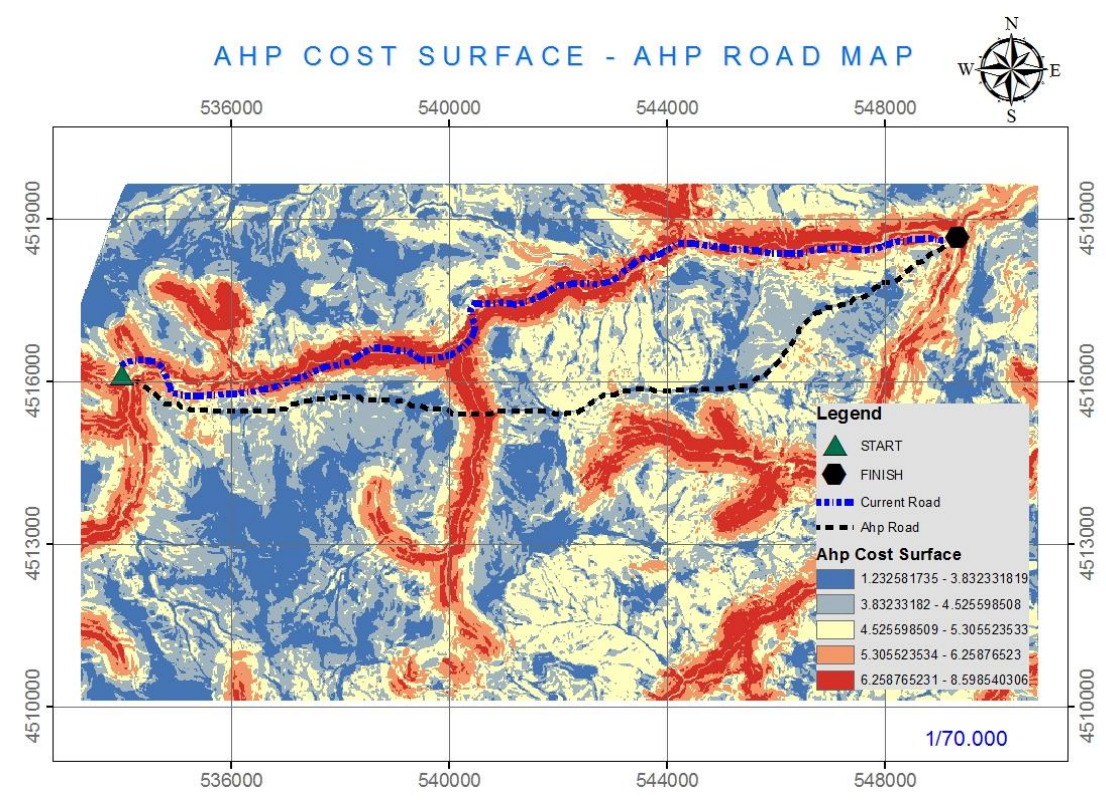

Figure 4. AHP cost surface, AHP route and current route

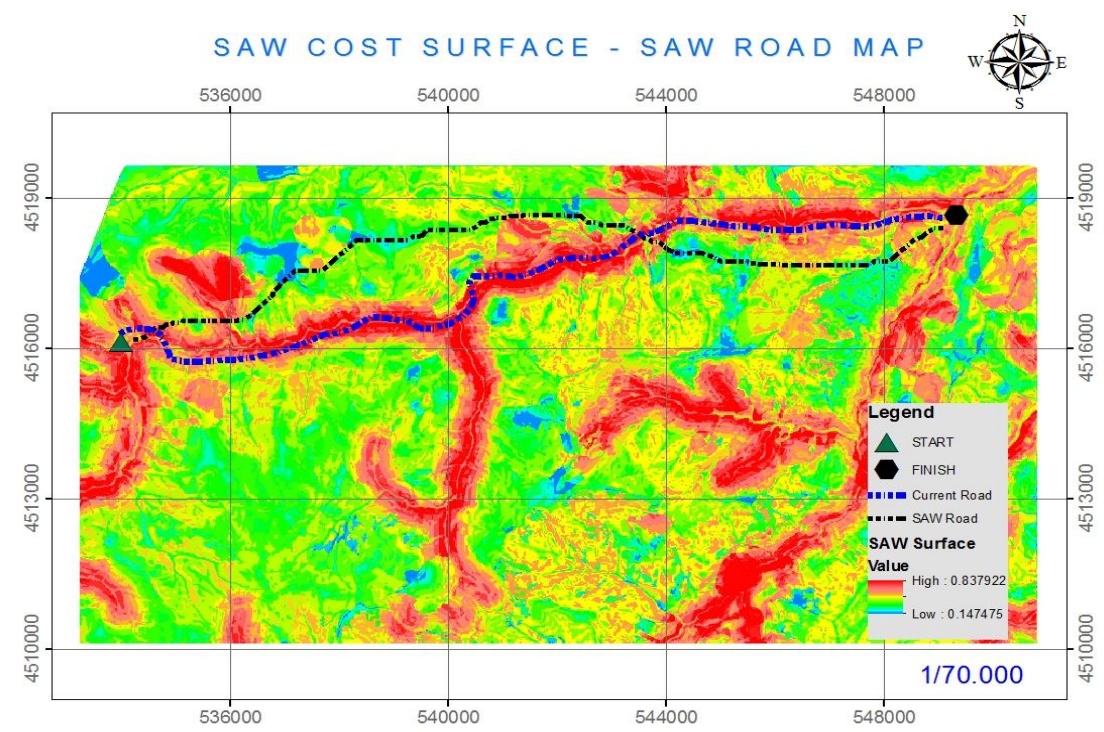

Figure 5. SAW cost surface, SAW route and current route 


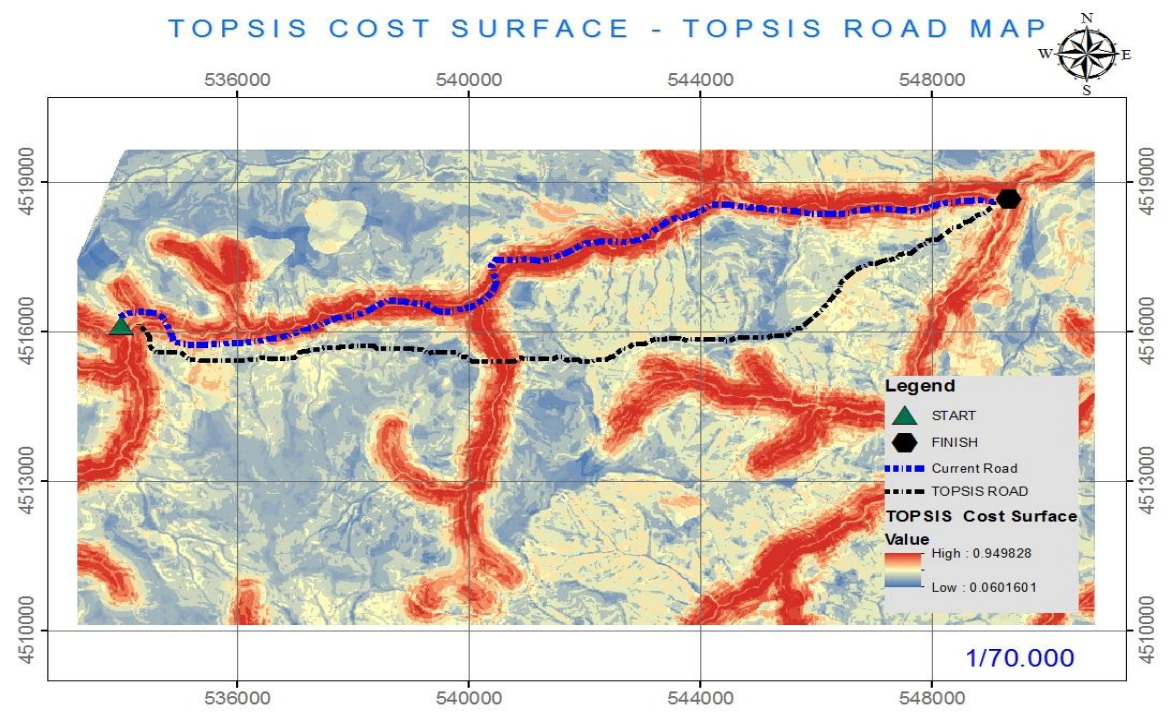

Figure 6. TOPSIS cost surface, TOPSIS route and current route

This paper puts forth a comprehensive method for comparing the most frequently used MCDM techniques and GIS with an automatic model in a case study on forest road route determination. 5 different forest road routes were determined following GIS based MCDM analysis. The manner of approach for discussing which method is suitable and effective for similar linear projects might be by the way of discussing each route respectively in terms of advantageous and disadvantageous results. In this section; one side we have discussed which MCDM technique gives the best offer and other side investigated, if our model is sensitive and acceptable in general.

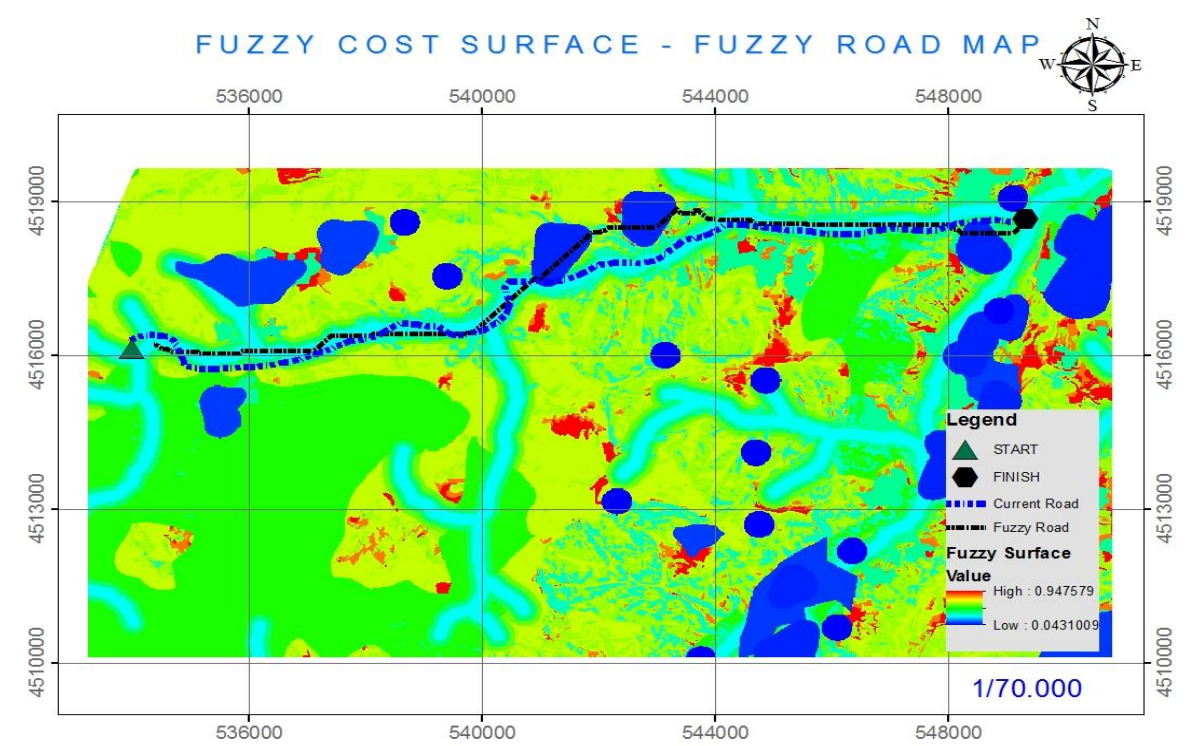

Figure 7. FUZZY cost surface, FUZZY route and current route 


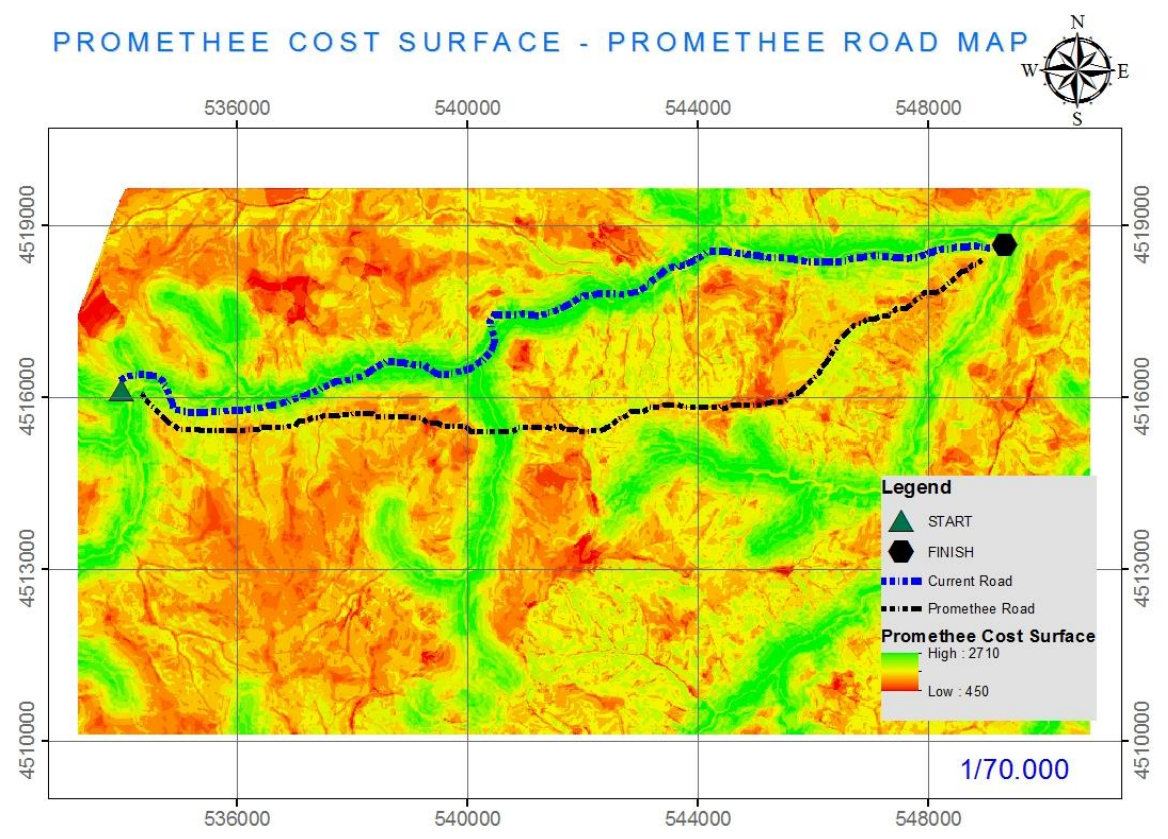

Figure 8. Promethee cost surface, Promethee route and current route

Table 2 shows these five generated forest road routes and the current road discussing in terms of coherency with given criteria (factor, sub-factor) weights. Values in Table 2 are quantity of intersection between route and related factor's geographic dataset. This Table summarizes 6 different routes (Promethee, TOPSIS, AHP, SAW, Fuzzy Overlay and Current Forest Road) as the suitability with given criteria before analysis. When we first consider Table 2, it can clearly be seen that Promethee is advantageous with regard to others. Promethee is advantageous in terms of given criteria's such as Avalanche, River and others. When all the criteria considered totally Promethee is the best method for this study.

No significant difference was observed between the total lengths of the result. The roads were calculated there isn't a big difference between generated 5 roads and current road. TOPSIS route is $16862 \mathrm{~m}$, SAW route is $16156 \mathrm{~m}$, Promethee route is $16420 \mathrm{~m}$, FUZZY route is $16288 \mathrm{~m}$, AHP route is $16828 \mathrm{~m}$ and current route is $17138 \mathrm{~m}$.

According to (Eq.1) formula, Promethee is the most effective method with a total CDI score of 175532,50 while the score of the Current Route was 331870,70 which was the worst. Other CDI scores are: TOPSIS- 182319, 3; AHP- 184552,8; SAW- 203678,2; FUZZY-316363,4. Therefore, the effectiveness ranking of MCDM techniques for Forest route determination can be listed as Promethee, TOPSIS, AHP, SAW and Fuzzy overlay according to our studies.

On the other hand, the selected GIS methods yielded sufficient per formation with regard to determining the optimum forest road route. Cost distance-cost path algorithms gives the best route on accumulated cost surface which is based on the case that all five forest road routes are more advantageous than the current forest road (Table 2). Calculation on raster pixels is the correct method on behalf of modelling the complete area in within the study borders. Also reclassifying all factor layers in same pixel resolution $(30 * 30$ meter in this application) has solved problems in the process of accumulated cost surface calculation. 
Table 2. Comparison of MCDM techniques from final forest roads

\begin{tabular}{|c|c|c|c|c|c|c|c|}
\hline Criteria & PASS & $\begin{array}{c}\text { Current } \\
\text { Road } \\
\text { (meters) }\end{array}$ & $\underset{\text { (meters) }}{\text { AHP }}$ & $\begin{array}{l}\text { FUZZY } \\
\text { (meters) }\end{array}$ & $\begin{array}{l}\text { TOPSIS } \\
\text { (meters) }\end{array}$ & $\begin{array}{c}\text { SAW } \\
\text { (meters) }\end{array}$ & $\begin{array}{c}\text { Promethee } \\
\text { (meters) }\end{array}$ \\
\hline Avalanche & PASS & 502,29 & 848,34 & 3025,22 & 855,66 & 1652,26 & 353,56 \\
\hline Erosion & $0-250 \mathrm{~m}$ & - & - & - & - & - & - \\
\hline \multirow{5}{*}{ Rivers } & $100 \mathrm{~m}$ & 10005,78 & 301,46 & 11277,72 & 308,33 & 885,77 & 223,79 \\
\hline & $200 \mathrm{~m}$ & 6155,96 & 449,96 & 491,93 & 341,75 & 618,06 & 310,86 \\
\hline & $300 \mathrm{~m}$ & 945,91 & 462,29 & 510,83 & 456,17 & 682,04 & 327,25 \\
\hline & $400 \mathrm{~m}$ & 31,14 & 519,07 & 568,09 & 627,94 & 767,18 & 389,63 \\
\hline & $500 \mathrm{~m}$ & - & 1928,65 & 971,54 & 1682,81 & 928,26 & 1368,22 \\
\hline $\begin{array}{c}\text { Protected } \\
\text { Areas }\end{array}$ & PASS & - & - & - & - & - & - \\
\hline $\begin{array}{c}\text { Natural } \\
\text { Resources }\end{array}$ & $250 \mathrm{~m}$ & - & 367,71 & - & 335,71 & - & 367,70 \\
\hline \multirow{3}{*}{ Soil } & 4 & - & - & - & - & 21,82 & - \\
\hline & 6 & 3275,46 & 3702,48 & 3072,55 & 3589,77 & 2206,11 & 3549,07 \\
\hline & 7 & 13863,23 & $\begin{array}{c}13139,9 \\
6\end{array}$ & 13230,47 & 13286,94 & 14298,04 & 12886,01 \\
\hline \multirow{3}{*}{ Geology } & Kru1-2-3 & 17138,69 & $\begin{array}{c}16842,4 \\
3\end{array}$ & 16303,03 & 16876,71 & 16526,37 & 15745,45 \\
\hline & Gama & - & - & - & - & - & - \\
\hline & $\mathrm{Jlh}$ & - & - & - & - & - & - \\
\hline \multirow{4}{*}{$\begin{array}{l}\text { Land } \\
\text { Cover }\end{array}$} & Meadow & 1296,74 & 1469,41 & 1681,25 & 1384,67 & 1784,55 & 1411,76 \\
\hline & Nut & 543,43 & 1728,37 & 2757,49 & 1604,11 & 4272,88 & 1377,08 \\
\hline & $\begin{array}{c}\text { Dry- } \\
\text { Agric. }\end{array}$ & 3824,57 & 455,36 & 2077,77 & 336,56 & 847,65 & 329,64 \\
\hline & $\begin{array}{c}\text { Forest } \\
\text { Settlemen } \\
\mathrm{t}\end{array}$ & $\begin{array}{c}11473,96 \\
-\end{array}$ & $\begin{array}{c}13189,3 \\
0 \\
- \\
\end{array}$ & $\begin{array}{c}9786,53 \\
-\end{array}$ & $\begin{array}{c}13551,36 \\
-\end{array}$ & $\begin{array}{c}9621,30 \\
-\end{array}$ & $\begin{array}{c}13316,60 \\
-\end{array}$ \\
\hline \multirow{6}{*}{ Slope } & $0-5$ & 167,99 & 909,22 & 316,16 & 1006,99 & 431,51 & 986,48 \\
\hline & $5,01-10$ & 446,92 & 1901,29 & 440,49 & 2037,97 & 1209,57 & 2050,40 \\
\hline & $10,01-20$ & 1346,33 & 6447,21 & 2052,63 & 6694,03 & 5991,98 & 6040,23 \\
\hline & $20,01-30$ & 4246,06 & 6266,39 & 2743,58 & 5796,59 & 6712,39 & 5958,70 \\
\hline & $30,01-40$ & 6265,64 & 1246,09 & 6140,66 & 1268,89 & 1861,39 & 1280,10 \\
\hline & $40,01-90$ & 4665,75 & 72,23 & 4609,51 & 72,23 & 319,19 & 119,17 \\
\hline $\begin{array}{l}\text { Total } \\
\text { Lenth }\end{array}$ & & 17138 & 16828 & 16288 & 16862 & 16156 & 16420 \\
\hline
\end{tabular}

Forest road planning with the lowest total construction costs is not always the best solution from an environmental point of view (Liu and Sessions, 1993; Dean, 1997; Chung and Sessions, 2001; Aruga, 2005; Akay, 2006; Hayati et al., 2012). In order to choose the best variant, it is necessary to take into account several criteria (Abdi et al., 2009; Gümüş, 2017).

As a result, an example sensitivity analysis for Promethee forest road route and cost surface was evaluated for this analysis. A python script was generated for this addition 
to our extension, FOROR. The function of the script is recalculation of the raster files by changing their weights with percent increase or decreases independent from each other. The sensitivity analysis shows that our GIS analysis is sensitive for 9 factors out of 10. The reason why the 1 factor (Protected Areas) is not sensitive is that there are a few protected areas on the field and this does not affect the analysis results significantly. Figures 9-10 show how the cost surface is changing when we change weights.

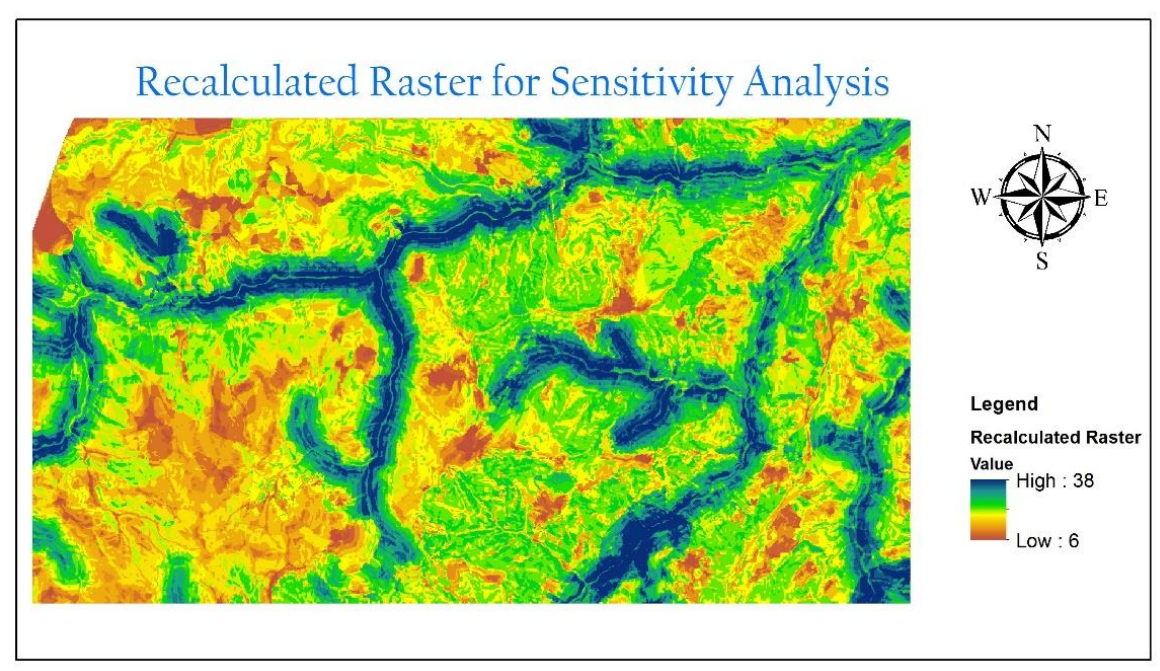

Figure 9. Cost surfaces showing recalculated surface for sensitivity analysis

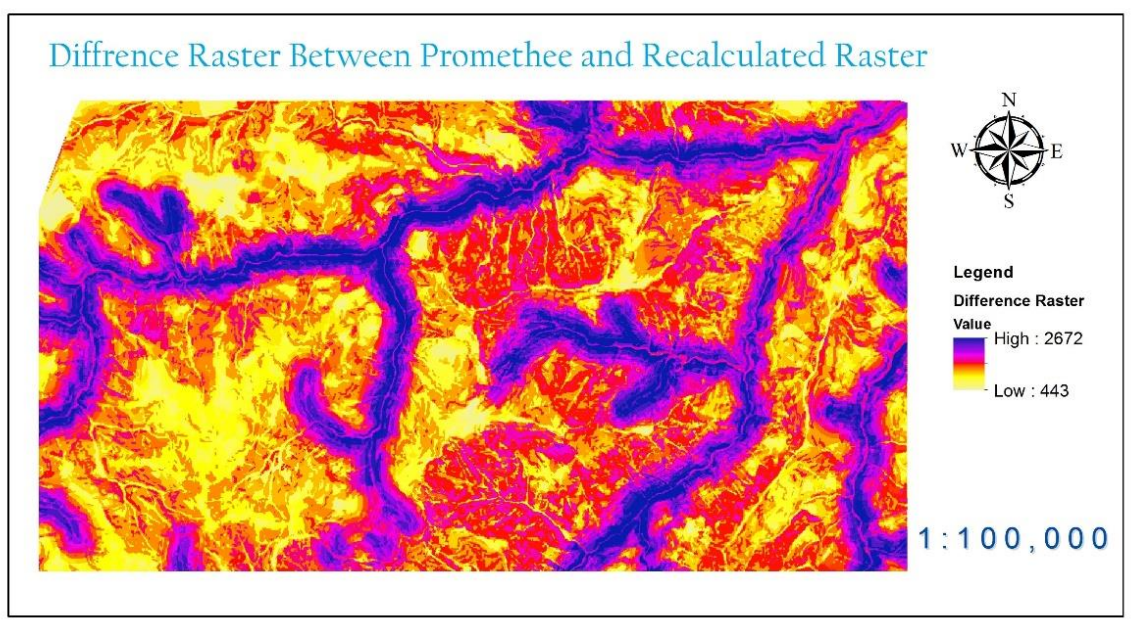

Figure 10. Cost surfaces showing difference between normal and recalculated surface

\section{Conclusion}

In this study, forest road route determination was dynamically realized using a rasterbased decision-support system based on GIS technologies developed by us, namely FOROR. The major factors which affect the forest road route and necessary geographic data layers were determined accordingly and were then classified according to the standards. For this application, Analytical Hierarchy Process (AHP), Simple Addition 
Weighting (SAW), Fuzzy Overlay, Promethee and TOPSIS methods of Spatial MultiCriteria Decision Methods (MCDM) were used. Analyses were performed using five different methods for the determination of forest routes which were then compared to each other as well as to the existing road.

Forest road route determination is a complex process because of these fields consist various environmental factors. Other sides there are many different aspects for choosing route, if the model is acted upon private sector just economic factors are significant other side aspect of academicians and environmental care groups focused on environmental factors. In this model we considered all of these different aspects and generated an optimum model both environment and economy saving.

Firstly, total length and low-high slope passes of route affects the economic efficiency and then other factors are considered for environmental caring. Clear results at Table 2 shows are saving environment, but for this purpose low slope area passes are decreased a bit. These new generated routes are balanced optimum routes, with considering all the aspects related to study area.

This paper shown that, using GIS based MCDM gives the best solution for forest road route determination. Especially Promethee resulted best offer, and it is likely to be the best method coherent with GIS. Creating context-specific extensions besides using GIS software is good solution for solving these complicated multidiscipline problems. Our extension FOROR put forth a good performance in analysis and when the results were compared. It has automated too many processes additionally minimizing human mistakes.

The combination of the methodologies used in this study and the forest road route criteria identified by the experts are suggested for future work in forest road routes in other regions.

\section{REFERENCES}

[1] Abdi, E., Majnounian, B., Darvishsefat, A., Mashayekhi, Z., Session, J. (2009): A GISMCE based model for forest road planning. - Journal of Forest Science 55(4): 171-176.

[2] Akay, A. E., Sessions, J. (2005): Applying The Decision Support System, TRACER, to Forest Road Design. - Western Journal of Applied Forestry 20(3): 184-191.

[3] Akay, A. E. (2006): Minimizing total costs of forest roads with computer-aided design model. - Sadhana- Academy Proceedings in Engineering Sciences 31(5): 621-633.

[4] Akay, A. E., Erdas, O., Reis, M., Yuksel, A. (2008): Estimating Sediment Yield from a Forest Road Network by Using a Sediment Prediction Model and GIS Techniques. Build. Environ. 43: 687-695.

[5] Altunel, A. O. (2000): Ormancılık Uygulamalarının Coğrafi Bilgi Sistemi ile Entegrasyonu (Forest aplication with GIS PhD.Thesis). - Yayınlanmamış Doktora Tezi. İ.Ü.Fen Bilimleri Enstitüsü.

[6] Arpacik, A., Sari A., Başkaya Ş. (2017): For the Future: Sustainable Wildlife Reserve Management in Turkey. - International Journal of Sciences: Basic and Applied Research (IJSBAR), vol.36: 250-261.

[7] Aruga, K. (2005): Tabu search optimization of horizontal ve vertical alignments of forest roads. - Journal of Forestry Research 10: 275-284.

[8] Bagli, S., Geneletti, D., Orsi, F. (2011): Routeing of power lines through least-cost path analysis and multicriteria evaluation to minimise environmental impacts. Environmental Impact Assessment Review 31: 234-239. https://doi.org/10.1016/j.eiar.2010.10.003. 
[9] Baidya, P., Chutia, D., Sudhakar, S., Goswami, C., Goswami, J., Saikhom, V., Singh, P., Sarma, K. (2014): Effectiveness of Fuzzy Overlay Function for Multi-Criteria Spatial Modeling-A Case Study on Preparation of Land Resources Map for Mawsynram Block of East Khasi Hills District of Meghalaya, India. - Journal of Geographic Information System 6: 605-612.

[10] Chen, H. L., Koprowski, J. L. (2016): Barrier effects of roads on an endangered forest obligate: influences of traffic, road edges, and gaps. - Biological Conservation, Volume 199: 33-40.

[11] Chiou, C., Tsai, W., Leung, Y. (2010): A GIS-dynamic segmentation approach to planning travel routes on forest trail networks in Central Taiwan. - Landscape and Urban Planning, Volume 97, Issue 4.

[12] Choi, Y., Park, H. D., Sunwoo, C., Clarke, K. C. (2014): Multi-Criteria Evaluation And Least Cost Path Analysis For Optimal Haulage Routing Of Dump Trucks In Large Scale Open-Pit Mines. - International Journal of Geographical Information Science, 23:12: 1541-1567.

[13] Chung, W., Sessions, J. (2001): Designing a forest road network using heuristic optimization techniques. - Council Engineering (COFE) Conference Proceedings: "Appalachian Hardwoods: Managing Change" Snowshoe, July 15-18.

[14] Çalışkan, E. (2013): Planning of forest road network and analysis in mountainous area. Life Sci Journal 10(2): 2456-2465.

[15] Çalışkan, E., Yıldırım, V., Bediroğlu, Ş. (2016): Foror- A Gıs Based Spatıal Multıple Criteria Decision Support Tool For Forest Road Route In Steep Terrain. - 1st International Symposium of Forest Engineering and Technologies, 02-04 June, Bursa, Turkey.

[16] Christian, T., Ravier, T., Cerin, C., Ngoko, Y. (2015): The Promethee Method for Cloud Brokering with Trust and Assurance Criteria. - 2015 IEEE.

[17] Dean, D. (1997): Finding optimal routes for networks of harvest site access roads using GIS-based techniques. - Canadian Journal of Forest Research 27: 11-22.

[18] Demir, M. (2007): Impacts, Management and Functional Planning Criterion of Forest Road Network System in Turkey. - Transport. Res. A-Pol. 41: 56-68.

[19] Demir, M., Öztürk, T. (2004): A Research on Forest Road Planning and Projecting by Inroads Software in Bolu Region of Turkey. - American Journal of Applied Sciences 1(4): 295-301.

[20] Ezzabadi, J. H., Saryazdi, M. D., Mostafaeipour, A. (2015): Implementing Fuzzy Logic and AHP into the EFQM model for performance improvement. - Appl. Soft Comput. 36, (November 2015), 165-176. DOI=http://dx.doi.org/10.1016/j.asoc.2015.06.051.

[21] Gümüş, S., Erdaş, O. (2000): Orman Yol Geçkilerinin Belirlenmesinde Coğrafi Bilgi Sistemlerinden Yararlanma İmkanları Üzerine Bir Araştırma (Forest road planning with GIS). - Turkish J. Agric. For. 24: 611-619.

[22] Gumus, S., Acar, H. H., Toksoy, D. (2008): Functional forest road network planning by consideration of environmental impact assessment for wood harvesting. - Environ Monit Assess 142: 109-116.

[23] Gumus, S. (2017):An Evaluation of Stakeholder Perception Differences in Forest Road Assessment Factors Using the Analytic Hierarchy Process (AHP), Forests, 8(5), 165.

[24] Hayati, E., Majnounian, B., Abdi, E., Sessions, J., Makhdoum, M. (2013): An expertbased approach to forest road network planning by combining Delphi and spatial multicriteria evaluation. - Environmental Monitoring and Assessment, Springer Publications, 185(2): 1767-1776.

[25] Hosseini, S. A., Solaymani, K. (2006): Investigation of effective factors for path tracing using GIS in Kheyroud forest (Iran-Mazadaran province). - Pakistan Journal of Biological Sciences 9(11): 2055-2061. 
[26] Joerin, F., Thériault M., Musy, A. (2001): Using GIS and outranking multicriteria analysis for land-use suitability assessment. - International Journal of Geographical Information Science 15(2): 153-174. DOI: 10.1080/13658810051030487.

[27] Jusoff, K. (2008): Construction of new forest roads in Malaysia using a GIS-based decision support system. - Computer and Information Science 1(3): 48-59.

[28] Kiker, G. A., Bridges, T. S., Varghese, A., Seager, T. P., Linkov, I. (2005): Application of multicriteria decision analysis in environmental decision making. - Integr Environ Assess Manag. 1: 95-108. doi:10.1897/IEAM_2004a-015.1.

[29] Kontos, D. T., Komilis, D. P., Halvadakis, C. P. (2005): Siting MSW landfills with a spatial multi criteria analysis methodolgy. - Waste Management 25: 818-832.

[30] Lee, J., Stucky, D. (1998): On Applying Viewshed Analysis for Determining LeastCostPaths on Dijital Elevation Models. - International Journal Geographical Information Science 12(8): 891-905.

[31] Liu, K., Sessions, J. (1993): Preliminary planning of roads using digital terrain models. Journal of Forest Engineering 4: 27-32.

[32] Malczewski, J. (1999): GIS and multicriteria decision analysis. - New York: John Wiley and Sons.

[33] Malczewski, J. (2006): GIS-based multicriteria decision analysis: a survey of the literature. - International Journal of Geographical Information Science 20(7): 703-726. DOI: $10.1080 / 13658810600661508$.

[34] Mohammadi Samani, K., Hosseiny, S. A., Lotfalian, M., Najafi, A. (2010): Planning road network in mountain forests using GIS and analytic hierarchical process (AHP). Caspian Journal of Environmental Sciences 8(2): 151-162.

[35] Murat, S., Kazan, H., Coskun, S. S. (2015): An Application for Measuring Performance Quality of Schools by Using the Promethee Multi-Criteria Decision Making Method. World Conference on Technology, Innovation and Entrepreneurship.

[36] Narulita, S., Fitriany Zain, A. F. M., Prasetyo, L. B. (2016): Geographic Information System (GIS) Application on Urban Forest Development in Bandung City. - Procedia Environmental Sciences 33: 279-289.

[37] Nino, K., Mamo, Y., Mengesha, G., Kibret, K. S. (2017): GIS based ecotourism potential assessment in Munessa Shashemene Concession Forest and its surrounding area, Ethiopia. - Applied Geography 82: 48-58.

[38] Rapaport, E., Snickars, F. (1998): GIS-based road location in Sweden: a case study to minimize environmental damage, building costs and travel time. - In: Stilwell, J., Geertman, S., Openshaw, S. (eds.) Geographical Information and Planning: 135-153. Springer, Heidelberg.

[39] Reutebuch, S. (1988): ROUTES: A Computer Program for Preliminary Route Location. U.D.o.A. PNRS, Forest Service. PNW-GTR-216.

[40] Rogers, L. (2005): Automating contour-based route projection for preliminary forest road designs using GIS. - [MS Thesis.] Washington, University of Washington: 87p.

[41] Saha, A. K., Arora, M. K., Gupta, R. P., Vırdı, M. L., Csaplovics, E. (2005): GIS-based route planning in landslide-prone areas. - International Journal of Geographical Information Science 19(10): 1149-1175.

[42] Saaty, T. L. (1980): The analytic hierarchy process. - New York: McGraw-Hill. 269p.

[43] Sac`kov, I., Smrecek, R., Tucek, J. (2014): Forest transportation survey based on airborne laser scanning data and GIS analyses. - GISci. Remote Sens. 51(1): 83-98.

[44] Sadeghi-Niaraki, A., Varshosaz, M., Kim, K., Jung, J. J. (2011): Real World Representation of a Road Network for RoutePlanning in GIS. - Expert Syst. Appl. 38(10): 11999-12008.

[45] Sadek, S., Berdan, M., Kaysi, I. (1999): GIS platform multi- criteria evaluation of route alignments. - Journal of Transportation Engineering 125(2): 144-151.

[46] Stergios, T., Stavros, S., Fani, S., Athanassios, S., Dirk, J., Olga, C. (2015): Mapping the optimal forest road network based on the multicriteria evaluation technique: the case 
study of Mediterranean Island of Thassos in Greece. - Environ Monit Assess 187: 687. DOI 10.1007/s10661-015-4876-9.

[47] Toinard, C., Ravier, T., Cérin, C., Ngoko, Y. (2015): The Promethee Method for Cloud Brokering with Trust and Assurance Criteria. - Proceedings- 2015 IEEE 29th International Parallel and Distributed Processing Symposium Workshops, 2015: 11091118.

[48] Yaralığlu, K. (2004): Uygulamada Karar Destek Yöntemleri (Aplication of Multi criteri decision method). - İlkem Ofset, İzmir, 2004.

[49] Yildirim, V., Yomralioglu, T., Nisanci, R., Çolak, E., Bediroğlu, Ş., Saralioglu, E. (2017): A spatial multicriteria decision-making method for natural gas transmission pipeline routing. - Structure and Infrastructure Engineering, 2016.

[50] Yoon, K., Hwang, C. L. (1980): Multiple Attribute Decision Making Methods and Applications: A State of the Art Survey. - Berlin: Springer Verlag.

[51] Yu, C., Lee, J., Stasiuk, M. J. M. (2003): Extensions to Least-Cost Path Algorithms for Roadway Planning. - International Journal of Geographic Information Science 17(4): 361-376.

[52] Zsigraiova, Z., Semiao, V., Beijoco, F. (2013): Operation costs and pollutant emissions reduction by definition of new collection scheduling and optimization of MSW collection routes using GIS: The case study of Barreiro, Portugal. - Waste Management 33(4): 793806. 